\title{
ディジタル仮想インピーダンス回路を用いた電磁シャント制振*
}

\author{
高木 賢太郎 $* 1$, 井上 剛志 $* 1$, 宮地 智也 $* 2$
}

\section{Electro-Magnetic Shunt Damping with a Digital Virtual Impedance Circuit}

\author{
Kentaro TAKAGI ${ }^{* 1}$, Tsuyoshi INOUE and Tomoya MIYACHI \\ *1 Mechanical Science and Engineering, Nagoya University \\ Furo-cho, Chikusa-ku, Nagoya, 464-8603 Japan
}

Electro-magnetic actuators have potentials of sensor-less vibration control due to the abilities of simultaneous actuation and sensing. This paper discusses a method of the electro-magnetic shunt damping with a digital virtual impedance circuit realizing a resistor or a resistor-capacitor circuit optimally designed by a theory of tuned mass damper. The digital virtual impedance circuit, which consists of a controlled voltage source and a computer, can realize arbitrary impedance. Using the virtual impedance concept, the optimally tuned resistive component which might have negative value can be realized, even though the conventional passive electro-magnetic shunt damping technique suffers from performance degradation due to the inherent resistance of the coil. The experimental results demonstrate the effectiveness of the proposed method. From the analysis of the open-loop transfer function, we also discuss the stability margin of the system and the suitability of the virtual impedance applied to the electro-magnetic shunt.

Key Words : Vibration Control Device, Electromagnetic Actuator, Smart Structure, Vibration Control, Dynamic Absorber

1.は じめ に

電磁アクチュエータは一般にもつとも広く用いられているアクチュエータの一つであり，とくに永久磁石を用い たものは機械エネルギーと電気エネルギーを相互に変換可能である.すなわち, 磁場中の電流に働くローレンツカ をアクチュエータとして, また逆に磁場中の運動によって生じる誘導起電力をセンサ (発電装置) としても利用で きる．乥こでこの特性を利用し，振動エネルギーを電気エネルギーに変換し制振効果を得ることや，回生されたエ ネルギーをもとに別のアクチュエータを駆動し振動を制御することが可能である (1) (2). また, 単一の電磁アクチュ エータに適切な外部電気回路 (シャント回路) を接続することでセンサレス制振を行う方法(電磁シャント制振)が 提案されている(3) (5).

電磁シャント制振のもつとも単純な場合は電磁アクチュエータの端子間を短絡したときであり, 弚れだけでも 若干の制振効果が得られる．しかしながらシャント回路を工夫することでより高い制振効果が得られる．たとえ ば，キャパシタを取り付けることで電気的な共振を利用し，大きな制振効果が得られることが知られている(3)(4). 著者らはシャント回路として抵抗とキャパシタを直列に接続した場合 (RC 回路) の最適設計式を動吸振器の定点理 論を元に導出した ${ }^{(4)}$. しかしながらコイルにはインダクタンスに加えて抵抗成分があり光の值が相対的に大きな ことがあるため，最適な抵抗值を実現するにはシャント回路に負の值をもつ抵抗が必要となる場合がある．弚の ため，正の值をもつ受動素子からなるシャント回路では所望の制振性能が得られないことが指摘されている(3)(4).

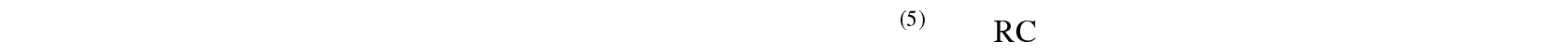
て電磁シャント制振を行っている.

\footnotetext{
* 原稿受付 2011 年 8 月 19 日

${ }^{* 1}$ 正員, 名古屋大学大学院工学研究科機械理工学専攻（广464-8603 愛知県名古屋市千種区不老町）

*2 名古屋大学大学院工学研究科機械理工学専攻

E-mail: takagi@nuem.nagoya-u.ac.jp
} 
電磁シャント制振と類似の手法として, 圧電材料を用いた圧電シャント制振と呼ばれる手法がスマート構造の分 野において知られている ${ }^{(6)}$. そのなかでアナログ電子回路や DSP(Digital Signal Processor)などのディジタル計算 機と電圧アンプによってインピーダンスを仮想的に実現した回路 (仮想インピーダンス回路) を用いたセンサレス 制振の手法が提案されている(7) (9) . 電磁シャント制振においても仮想インピーダンス回路を用いることができれ ば，センサレスという利点に加えて，最適設計された回路素子值の実現も容易に可能となる．乥こで本研究では， ディジタル制御された仮想インピーダンス回路が電磁アクチュエータのセンサレス制振に利用できることをモデ ルと実験により明らかにし，動吸振器の理論により最適設計された R 回路もしくは RC 回路を仮想的に実現する 方法を提案する.最適設計された R 回路と RC 回路を模擬するために, 物理的な受動素子を用いる従来の方法 ${ }^{(4)}$ では実現できなかった負の值をもつ抵抗を仮想的に実現する．なお，ディジタル制御された仮想インピーダンス 回路を用いることで, オブザーバや最適制御などによる現代的な制御系設計も今後期待できる . しかし本論文で は高度な振動制御系設計に進む前の段階として，コントローラがもつとも単純となる $\mathrm{R}$ 回路もしくは RC 回路を 模擬する場合を検討する $\mathrm{R}$ 回路と RC 回路を模擬しているため従来の手法 ${ }^{(3)}$ (4) $^{(1}$ 自然な拡張であり，簡易な設計 式によってコントローラのパラメータを一意に定められる．また，仮想インピーダンス回路を電磁シャント制振 に利用した場合における系の物理的特徵についても議論する．

本論文の構成は以下の通りである . はじめに, ばね・質量と電磁アクチュエータからなる系の支配方程式を導 出し，抵抗もしくは抵抗とキャパシタからなるシャント回路を用いた場合の安定性の解析と素子值の最適設計 ${ }^{(4)}$ を示す. 光して閉ループ系の伝達関数を用いた解析と数值例により制振効果に対する考察を加える.続いて, 計 算機と電圧アンプからなる仮想インピーダンス回路の構成を示し，インピーダンスをディジタル制御する方法を 確認する.計算機の $\mathrm{AD}$ 入力部分で制御ループを切断したときの開ループ伝達関数を示し, 系の特性と安定余裕 について考察する．また，圧電シャント制振にディジタル仮想インピーダンス回路を適用した場合 ${ }^{(10)}$ とは異なり， ディジタル化に際して平滑化フィルタや安定化補償が不要であるという特長を明らかにし, 弚の意味でディジタ ル仮想インピーダンス回路は電磁シャント制振に適した回路であることを示す. 最後に , 仮想インピーダンス回路 を作製し，電磁アクチュエータが取り付けられた 1 自由度台車の制振実験を行う. 実験結果から，提案手法の有 効性を示す．

$$
\text { 2. モ デル }
$$

\section{$2 \cdot 1$ 支配方程式}

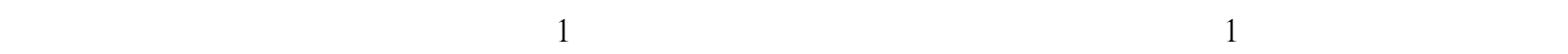
実験装置を示す．電磁アクチュエータ (図 1 右) は永久磁石とコイルから構成されており，加えた電流に比例して ローレンツカが生じ, また逆に速度に比例して誘導起電力が生じる.電磁アクチュエータには外部電気回路(シャ ント回路) ガ取り付けられている . 図 2 は質量をもつ台車の運動を表す系 (以降機械系と呼ぶ) の概念図であり, 図 3 はコイルの等価回路と光れに接続されたシャント回路を表す系 (以降電気系と呼ぶ)の概念図である. 機械系と 電気系は電磁力と誘導起電力により互いに影響を及ぼしている.なお図中で用いた変数とパラメータを光れぞれ 表 1 と表 2 に示す．まず機械系の支配方程式は以下のようになる.

$$
m \ddot{x}(t)+c \dot{x}(t)+k x(t)=f_{a}(t)+f_{d}(t)
$$

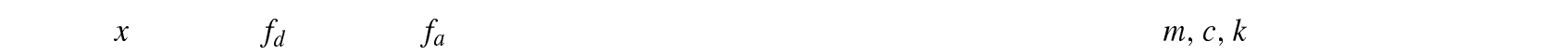
減衰係数, ばね係数を表し, 正の定数である. 変位が十分に小さくまた電磁アクチュエータの磁束むらが小さい と仮定すると，ローレンツカはコイルに流れた電流に比例する . 兴のため， $f_{a}$ は以下のように表せる .

$$
f_{a}(t)=\phi i_{s}(t)
$$

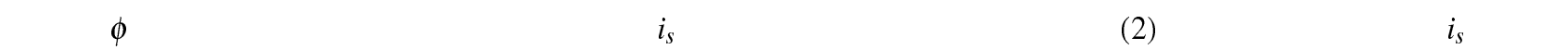
て正の電磁力が生じるように電流 $i_{s}$ の向きを定める . 回路中の起電力についても， $i_{s}$ を生じさせる方向を正にと るものとする . 回路方程式をコイル部分とシャント回路部分でわけて書くと , 次のようになる .

$$
\begin{aligned}
L \frac{d i_{s}(t)}{d t}+R_{L} i_{s}(t) & =v_{L}(t)-v_{s}(t) \\
\tilde{v}_{s}(s) & =Z_{s}(s) \tilde{i}_{s}(s)
\end{aligned}
$$


ここで $Z_{s}$ はシャント回路のインピーダンスであり, $v_{s}$ はシャント回路の端子間電圧,$v_{L}$ は電磁誘導による起電力 である.$L$ と $R_{L}$ は乥れ光れ電磁アクチュエータのインダクタンスと抵抗を表し，正の定数である.設計者によっ てシャント回路は自由に変更できるため, 光のインピーダンスは伝達関数 $Z_{s}$ を用いて一般的に表してある . なお， 本論文ではラプラス変換された関数を，たとえば $v_{s}(t)$ から $\tilde{v}_{s}(s)$ のように表す．また，運動によってコイルに生じ る誘導起電力 $v_{L}$ は速度に比例し運動を妨げる向きに発生するため，次のように表すことができる．

$$
v_{L}(t)=-\phi \dot{x}(t)
$$

式 (1)，(2)，(3)，(4)，(5)が系の支配方程式となる .
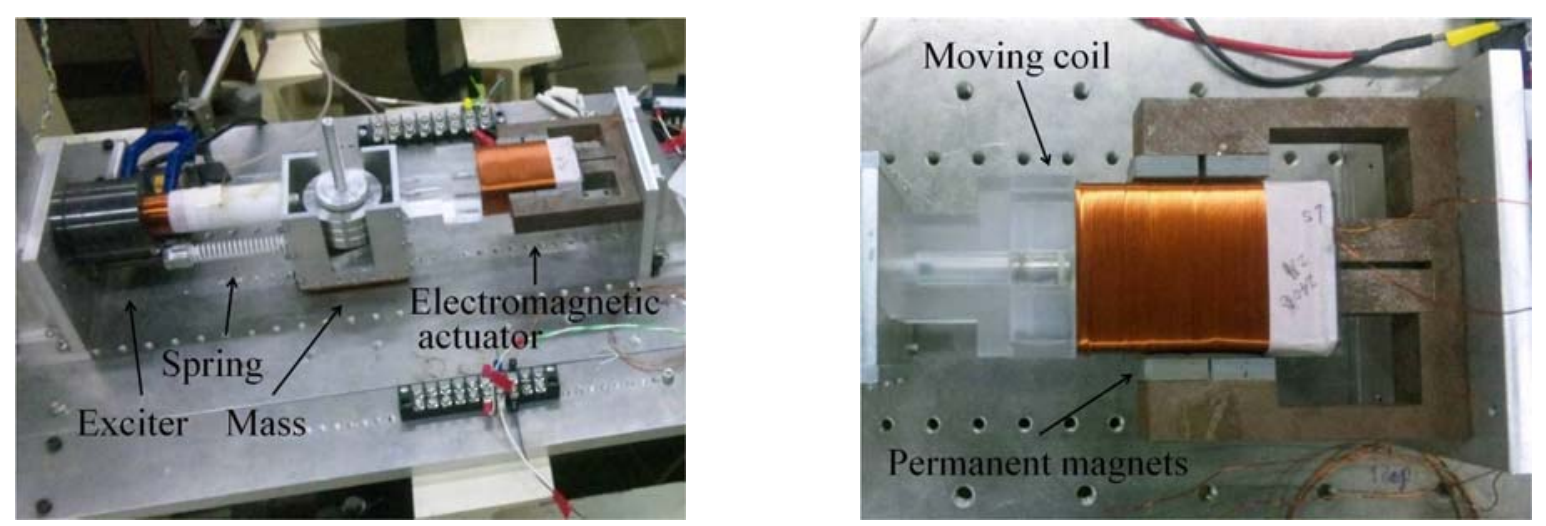

Fig. 1 Pictures of the electro-magnetic shunt damper (left: overview, right: electromagnet)

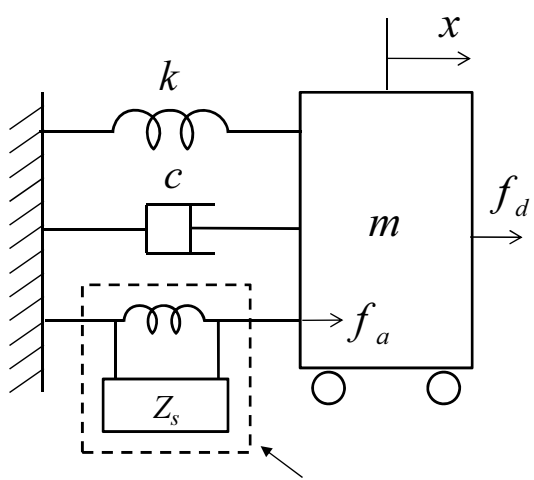

Shunted electro-magnetic actuator

Fig. 2 Mechanical system model

Table 1 Variables

\begin{tabular}{lll}
\hline \hline$x$ & Displacement & {$[\mathrm{m}]$} \\
$f_{d}$ & Disturbance force & {$[\mathrm{N}]$} \\
$f_{a}$ & Induced electromotive force & {$[\mathrm{N}]$} \\
$v_{s}$ & Terminal voltage across the shunt circuit & {$[\mathrm{V}]$} \\
$v_{L}$ & Induced voltage in the coil & {$[\mathrm{V}]$} \\
$i_{s}$ & Current flowing into the shunt circuit & {$[\mathrm{A}]$} \\
\hline \hline
\end{tabular}

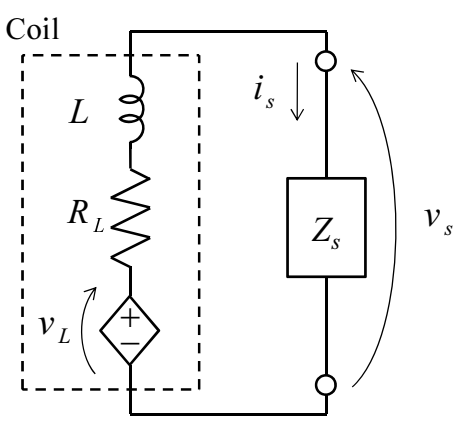

Fig. 3 Electrical system model

Table 2 Parameters

\begin{tabular}{rll}
\hline \hline$m$ & Mass & {$[\mathrm{kg}]$} \\
$c$ & Damping coefficient & {$[\mathrm{Ns} / \mathrm{m}]$} \\
$k$ & Spring constant & {$[\mathrm{N} / \mathrm{m}]$} \\
$\phi$ & Couping coefficient & {$[\mathrm{N} / \mathrm{A}]$ or $[\mathrm{Vs} / \mathrm{m}]$} \\
$L$ & Inductance of the coil & {$[\mathrm{H}]$} \\
$R_{L}$ & Resistance of the coil & {$[\Omega]$} \\
\hline \hline
\end{tabular}

\section{$2 \cdot 2$ 電磁シャント制振系の解析と設計}

\subsection{1 閉ループ系の伝達関数}

外力 $f_{d}$ から変位 $x$ までの伝達関数 $G_{x f}(s)$ を求める . まず, 式 (1) , (2) , (3) , (4) , (5) をラプラス変換する. プラス変換された式 $(3),(4)$ より $\tilde{v}_{s}$ を消去し $\tilde{v}_{L}$ から $\tilde{i}_{s}$ までの伝達関数を $Y_{\mathrm{el}}(s)$ とおく.

$$
Y_{\mathrm{el}}(s):=\frac{\tilde{i}_{s}}{\tilde{v}_{L}}=\frac{1}{L s+R_{L}+Z_{s}(s)}
$$


式 (2)，(5)，(6)より， $Y_{\mathrm{el}}(s)$ を用いて電磁力 $\tilde{f}_{a}$ を表すと

$$
\tilde{f}_{a}(s)=-\phi^{2} s Y_{\mathrm{el}}(s) \tilde{x}(s)
$$

となる. 㶢して, 式 (1), (7) より $\tilde{f}_{a}$ を消去すると, 外力 $f_{d}$ から変位 $x$ までの伝達関数 $G_{x f}(s)$ は

$$
G_{x f}(s)=\frac{1}{m s^{2}+\left(c+\phi^{2} Y_{\mathrm{el}}(s)\right) s+k}
$$

と得られる . シャント回路の動特性は電気系のアドミタンス $Y_{\mathrm{el}}$ に含まれている . 図 4 は系のブロック線図であり， 機械系, コイル, シャント回路の相互接続関係が示されている.図中一点鎖線は電気系のアドミタンス $Y_{\mathrm{el}}$ を表し ており， $Y_{\mathrm{el}}$ がコイルのアドミタンスとシャント回路のインピーダンスからなることがわかる . 本研究ではシャン 卜回路の種類として， $Z_{s}$ に何も接続せず開放した場合， $Z_{s}$ が抵抗の場合， $Z_{s}$ が直列に接続した抵抗とキャパシタ の場合の 3 つについて述べる .

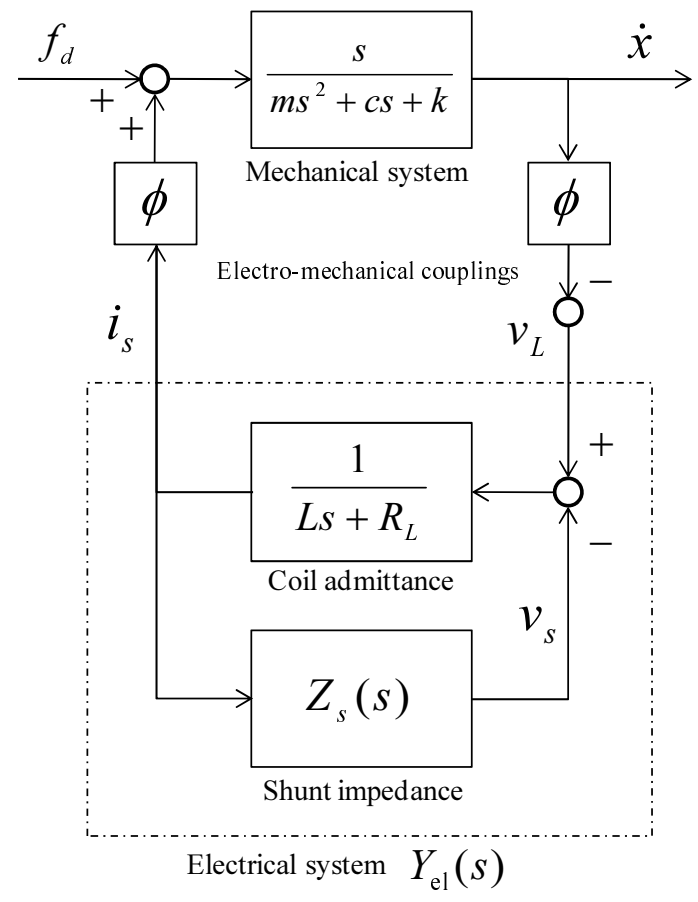

Fig. 4 Block diagram of the electro-magnetic shunt damping system

\subsection{2 端子間開放の場合}

シャント回路を接続せずコイルの両端を開放した場合を考える .このときシャント回路のインピーダンスは無 限大とみなせるので ,

$$
Z_{s}^{\text {(open) }} \rightarrow+\infty
$$

とおくと, 式(6)より $Y_{\mathrm{el}}^{(\text {open })} \rightarrow 0$ となる.これを式 (8) に代入すると, 端子間開放の場合 $f_{d}$ から $x$ までの伝達関 数は次のようになる.

$$
G_{x f}^{(\text {open })}(s)=\frac{1}{m s^{2}+c s+k}
$$

すなわち，端子間を開放した場合には電磁力による効果は無くなることがわかる.なお，端子間を開放した場合， 抵抗のみ接続した場合，抵抗とキャパシタを直列に接続した場合のどれにあたるかがわかるように，伝達関数の 右肩には括弧で (open) などと添え字をつけるものとする .

\subsubsection{R シャントの場合}

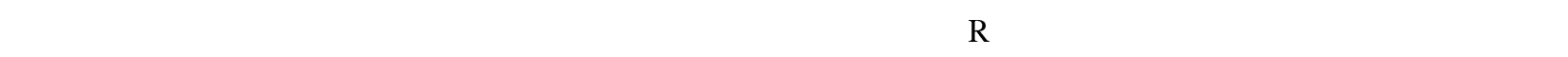
た場合も抵抗が 0 の素子を接続したとみなすことができるため，この場合に含まれる．接続した抵抗素子の抵抗 
值を $R_{s}$ とするとシャント回路のインピーダンスは以下のように表せる.

$$
Z_{s}^{(\text {Rshunt })}(s)=R_{S}
$$

これを式(6)に代入すると

$$
Y_{\mathrm{el}}^{(\mathrm{Rshunt})}(s)=\frac{1}{L s+R_{L}+R_{s}}
$$

となり，さらに式 $(8)$ に代入することで, $\mathrm{R}$ シャントの場合における $f_{d}$ から $x$ までの伝達関数は次のようになる.

$$
G_{x f}^{\text {(Rshunt) }}(s)=\frac{L s+R_{L}+R_{s}}{m L s^{3}+\left(m\left(R_{L}+R_{s}\right)+c L\right) s^{2}+\left(c\left(R_{L}+R_{s}\right)+k L+\phi^{2}\right) s+k\left(R_{L}+R_{s}\right)}
$$

従来の電磁シャントダンパでは外部電源は無く受動素子のみを用いるため系の安定性は保証される.しかし，仮 想インピーダンスを用いた手法では $R_{S}$ の值は自由に設計できるため, 式 (12) で表される系の安定性について考 察する必要がある.設計パラメータ $R_{s}$ 以外の物理パラメータはすべて正であることに注意すると , ラウス・フル

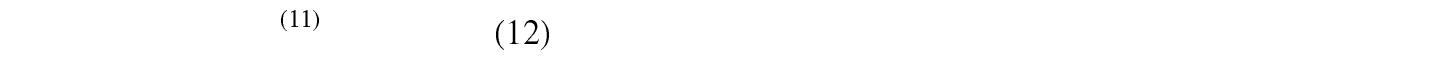

$$
\left\{\begin{array}{l}
m\left(R_{L}+R_{S}\right)+c L>0 \\
c\left(R_{L}+R_{S}\right)+k L+\phi^{2}>0 \\
k\left(R_{L}+R_{S}\right)>0 \\
m c\left(R_{L}+R_{s}\right)^{2}+\left(m \phi^{2}+c^{2} L\right)\left(R_{L}+R_{s}\right)+c L\left(k L+\phi^{2}\right)>0
\end{array}\right.
$$

この連立不等式は $R_{S}$ が正であれば成立する.$R_{S}$ を負の方向へ小さくしていったとき，連立不等式の中で最も厳し い条件は $k\left(R_{L}+R_{S}\right)>0$ である.よって, 式 (12)が漸近安定であるための必要十分条件は次式で与えられる.

$$
R_{S}>-R_{L}
$$

$R_{s}$ の最適設計にはダンパや動圾振器の設計でよく用いられる定点理論を用いる.なお， $\mathrm{R}$ シャントの効果はば ねと直列に接続されたダンパとして類推ができ，フードダンパ(Houde Damper)にも似ていることが知られている ${ }^{(4)}$. 文献 ${ }^{(4)} よ り$, 式 (12) に示す伝達関数のピークゲインを最小化する意味で最適な $R_{s}$ の值を求めると次式で表さ れる.

$$
R_{s}^{\mathrm{opt}(\mathrm{Rshunt})}=-R_{L}+L \sqrt{\frac{k}{m}\left(1+\frac{\phi^{2}}{2 k L}\right)}
$$

$R_{s}^{\mathrm{opt}(\mathrm{Rshunt})}$ は，式 (14) に示した漸近安定であるための条件を明らかに満足している.なお， $R_{s}^{\mathrm{opt}(\mathrm{Rshunt})}$ の值は $R_{L}$ の大きさによっては負となる場合もあり，実際に後述の実験では負の值をとる．

\subsubsection{RC シャントの場合}

次にシャント回路として抵抗素子とキャパシタを直列に接続した場合を考え，これを RCシャントと呼ぶ . シャ

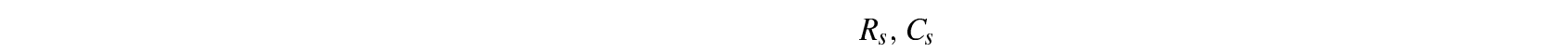
以下のように表せる .

$$
Z_{s}^{(\mathrm{RCshunt})}(s)=R_{s}+\frac{1}{C_{s} s}
$$

これを式(6)に代入すると，

$$
Y_{\mathrm{el}}^{(\mathrm{RCshunt})}(s)=\frac{C_{s} s}{L C_{S} s^{2}+\left(R_{L}+R_{s}\right) C_{s} s+1}
$$

となり，さらに式 $(8)$ に代入することで, RC シャントの場合における $f_{d}$ から $x$ までの伝達関数は次のようになる .

$$
G_{x f}^{(\mathrm{RCshunt})}(s)=\frac{L C_{s} s^{2}+\left(R_{L}+R_{s}\right) C_{s} s+1}{m L C_{s} s^{4}+\left(m\left(R_{L}+R_{s}\right) C_{s}+c L C_{s}\right) s^{3}+\left(m+c\left(R_{L}+R_{s}\right) C_{s}+\left(k L+\phi^{2}\right) C_{s}\right) s^{2}+\left(c+k\left(R_{L}+R_{s}\right) C_{s}\right) s+k}
$$


$C_{s}, R_{s}$ 以外のパラメータが正值であることに注意すると, 式 (18)の伝達関数が漸近安定であるための必要十分 条件はラウス・フルビッツの安定判別法より次のように求められる .

$$
\left\{\begin{array}{l}
m L C_{s}>0 \\
m\left(R_{L}+R_{s}\right) C_{s}+c L C_{s}>0 \\
m+c\left(R_{L}+R_{s}\right) C_{S}+\left(k L+\phi^{2}\right) C_{s}>0 \\
c+k\left(R_{L}+R_{S}\right) C_{s}>0 \\
m c C_{s}^{2}\left(R_{L}+R_{s}\right)^{2}+\left(\left(c^{2} L+m \phi^{2}\right) C_{s}+m^{2}\right) C_{s}\left(R_{L}+R_{s}\right)+\left(c k L^{2}+c \phi^{2} L\right) C_{s}^{2}>0 \\
m c k C_{s}^{3}\left(R_{L}+R_{s}\right)^{3}+\left(\left(c^{2} k L+m k \phi^{2}\right) C_{s}+m c^{2}\right) C_{s}^{2}\left(R_{L}+R_{s}\right)^{2} \\
\quad+\left(c k \phi^{2} L C_{s}^{2}+\left(c^{3} L+m c \phi^{2}\right) C_{s}+c\left(k L C_{s}-m\right)^{2}\right) C_{s}\left(R_{L}+R_{s}\right)+c^{2} \phi^{2} L C_{s}^{2}>0
\end{array}\right.
$$

ここで, 設計パラメータ $C_{s}, R_{s}$ が , 次の条件

$$
C_{s}>0, \quad R_{s}>-R_{L}
$$

を満たせば式 (19) は満足される . 谷のため, 式 (18)の伝達関数が漸近安定となるための十分条件は式 (20)で与え られる。

前述の R シャントの効果が直列ばねダンパて類推できるように， RC シャントの効果は動吸振器として類推が可 能である. 乥のため, 定点理論を用いてピークゲインを最小化する意味で最適な抵抗 $R_{s}^{\mathrm{opt}}$ と静電容量 $C_{s}^{\mathrm{opt}}$ を求め ることができる．電気機械結合係数 $\phi$ が $\phi^{2}<2 k L$ を満たす場合を仮定すると，文献 ${ }^{(4)}$ り次のように求められる .

$$
\left\{\begin{array}{l}
C_{S}^{\text {opt(RCshunt) }}=\frac{m}{k L\left(1-\frac{\phi^{2}}{2 k L}\right)} \\
R_{S}^{\text {opt(RCshunt) }}=-R_{L}+\frac{\phi}{4} \sqrt{\frac{L}{m}}\left(\sqrt{6+2 \sqrt{\frac{\phi^{2}}{2 k L}}}+\sqrt{6-2 \sqrt{\frac{\phi^{2}}{2 k L}}}\right)
\end{array}\right.
$$

明らかに, 式 (21) は式 (20) を満足する.また, $\mathrm{R}$ シャントの場合と同樣, $R_{s}^{\mathrm{opt}(\mathrm{RChhunt})}$ は負の值となり得る.

なお，電気機械結合係数が $\phi^{2}<2 k L$ を満たすような上述の場合には，回路の共振を利用する $\mathrm{RC}$ シャントは $\mathrm{R}$ シャントよりも一般に性能が高い(4) ${ }^{(4)}$ しかしがら, 電気機械結合係数 $\phi$ が $\phi^{2} \geq 2 k L$ となる場合, RC シャントの 制振性能は R シャントの光れよりも劣化するとされている(4) $\phi^{2}=2 k L$ の場合に低周波側の定点が $0[\mathrm{rad} / \mathrm{s}]$ に一致してしまうことに原因があり，またこのとき式 (21) において $C_{s}^{\mathrm{opt}(\mathrm{RCShunt})} \rightarrow \infty$ となってしまう.すなわち,$\phi^{2} \geq 2 k L$ の場合，二つの定点のゲインの大きさを一致させるという 定点理論の規範では RC シャントの適切な設計ができない．また光のような場合は電気機械結合がきわめて高く， $\mathrm{RC}$ シャントではなく $\mathrm{R}$ シャントであっても全く振動しない (過減衰) 系にすることができる．乥こで，本論文で

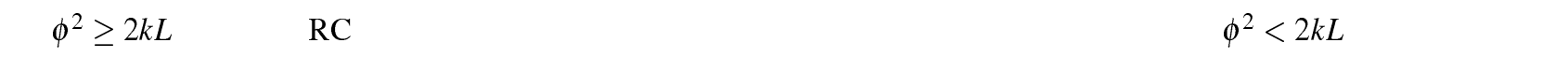
認している.

\section{$2 \cdot 3$ 数值例}

前節で求めた伝達関数 $G_{x f}$ のボード線図を図 5 に示す . 左に $\mathrm{R}$ シャントの場合 , 右に RC シャントの場合を示 す . 用いたパラメータは後述の実験と同じ値である . またこの数值例の場合 , 定点理論によって設計された $R_{s} の$ 最適值は負となる．図中一点鎖線は回路開放時であり，実線は $R_{s} に$ に最適值を用いた理想的な場合，一点鎖線は $R_{s}$ を0とおいた場合 (回路を短絡した場合)である．

图 5 の左側に示す R シャントの場合では，回路を開放したときと比較すると，理想的な場合ではピークゲイン の低減は約 $-17[\mathrm{~dB}]$ ，つまり最大振幅は約 $1 / 7$ になっている．R $R_{s}$ を負の最適值ではなく 0 においた場合では，ゲ

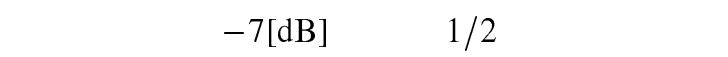

図 5 の右側に示す RC シャントの場合では，回路を開放した場合と比べ理想的な場合ではピークゲインが約 $-27[\mathrm{~dB}]$ ，つまり最大振幅力約 $1 / 22$ になっており，理想的な $\mathrm{R}$ シャントの場合と比較してもさらに大きな制振効 果があることがわかる.こちらも $R_{s}$ を負の最適值ではなく0においた場合では，ゲイン低減は約 $-7[\mathrm{~dB}]$ 程度し 
かない .すなわち , R シャントと RC シャントいずれの場合においても最適な抵抗值は負であるため, コイル端子 間を短絡したとしても所望の制振効果は望めないことがわかる．

次に，制振性能の評価について検討を加えるため，電気系のアドミタンス $Y_{\mathrm{el}}$ に着目する . 図 6 は $Y_{\mathrm{el}}(s)$ のボー ド線図である．なお，ボード線图では単位を無次元化して減衰比に光ろえるために $\phi^{2} /(2 \sqrt{m k})$ を乗じてある.図 4 ならびに式 $(8)$ に示すように，機械系の力から変位までの伝達関数 $G_{x f}(s)$ において, $\phi^{2} s Y_{\mathrm{el}}(s)$ は機械系からみて 電気系の効果がフィードバックされる項である． $Y_{\mathrm{el}}(s)$ の位相が 0 であるとき電磁力は速度と逆位相となり，ちょ うど速度フィードバックと同樣な効果が期待できる. 光のため, $Y_{\mathrm{el}}(s)$ は機械系の固有角振動数付近でゲインが高 くかつ位相が 0 となっていることか望ましい．図 6 中では，最適值を用いた場合の $Y_{\mathrm{el}}(s)$ のボード線図を実線で 示し, 機械系の固有角振動数 $\sqrt{k / m}$ の值を破線で示している.機械系の固有角振動数において, $\mathrm{R}$ シャントの場

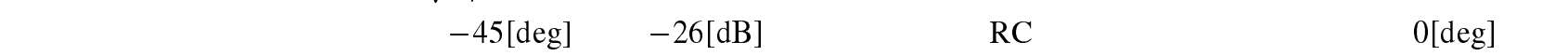
り，ゲインも約 $-16[\mathrm{~dB}]$ と R シャントよりも高い .このことから， R シャントよりも RC シャントのほうがより 良好な制振性能をもつ理由が, $Y_{\mathrm{el}}(s)$ の特性からも確認できる．なお，図 6 中の一点鎖線は $R_{s}$ を最適值ではなく

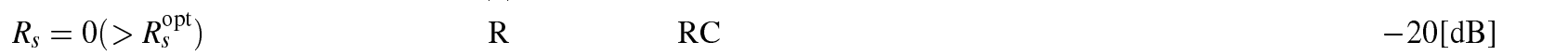
ゲインが低下している，弚のため, 最適值の場合と比べて電磁力もしくは減衰比は一桁小さくなり, 図 5 で示し たように制振性能が劣化する。
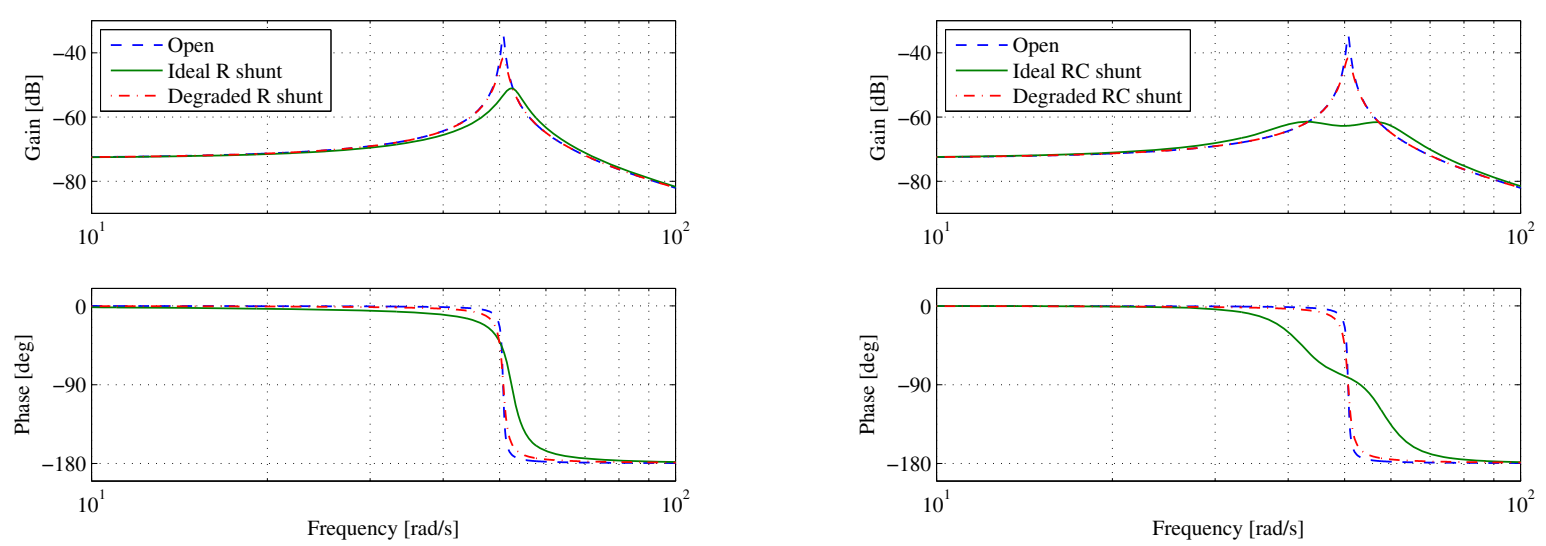

Fig. 5 Bode diagram of $G_{x f}(s)$ (left: with R shunt circuit, right: with RC shunt circuit)
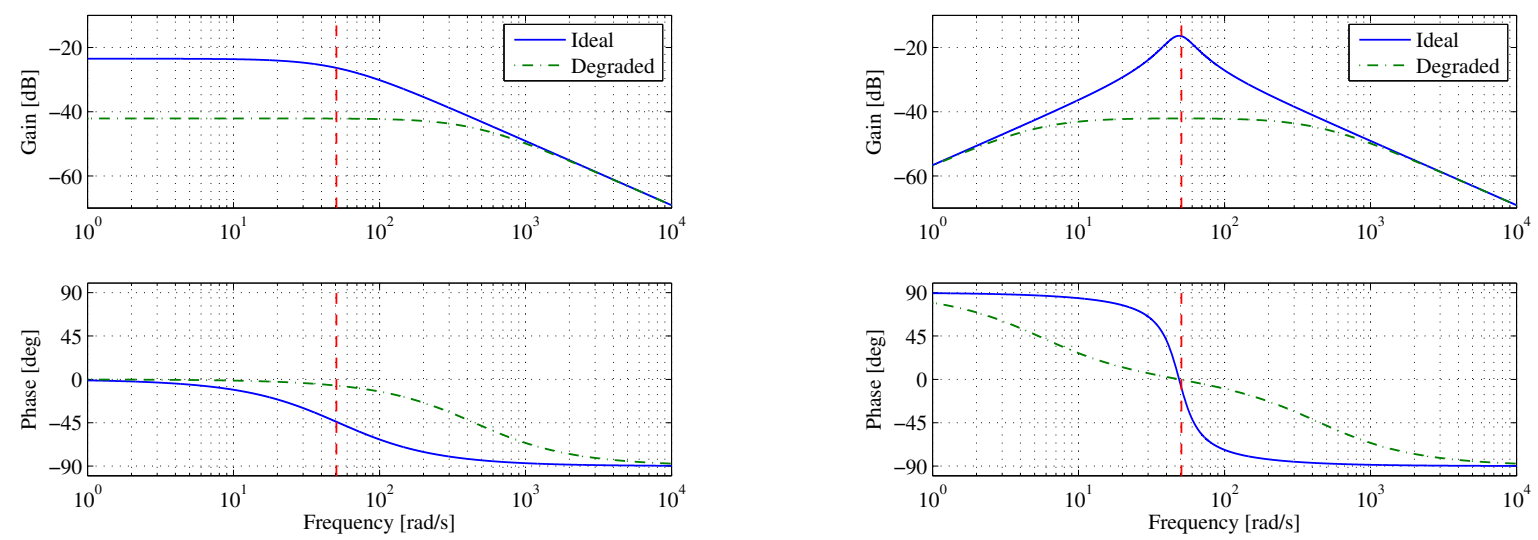

Fig. 6 Equivalent damping ratio, $\phi^{2} Y_{\mathrm{el}}(s) /(2 \sqrt{m k})$ (left: R shunt, right: RC shunt)

\section{3. 仮想インピーダンスによる電磁シャント制振}

$3 \cdot 1$ 仮想インピーダンス

電磁シャント制振において, シャント回路に必要な抵抗值は非常に小さな值もしくは負の値になる場合が多い． また， RC シャントの場合には大きな静電容量をもつキャパシタが必要になる。物理的な抵抗やキャパシタでは， 
素子自身が正の抵抗成分を持つために最適值を実現することが困難か不可能となる場合がある．弚のため本論文 では，仮想インピーダンス回路をシャント回路として用いることを提案する．仮想インピーダンス回路を用いる ことで負性抵抗が実現できるため，最適なパラメータをもつ回路を模擬できる．さらに，自由にインピーダンス を調整できることは将来的に高度な制振，振動制御への可能性を与える．

仮想インピーダンス回路とは, 受動素子を配置する代わりに電圧アンプを用いて关の電圧を適切に出力するこ とで，あたかも光こに所望のインピーダンスが接続されたかのようにする方法である ${ }^{(7) ~(9)}$. 図 7 に仮想インピー ダンスの概念図を示す．図７において，(a) は物理的なシャント回路によるインピーダンス $Z_{s}$ である . (a) と同じ インピーダンスを制御電圧源により実現する.弚こで，まず(a)に示すインピーダンスを(b)に示すように3つに 分割する.$Z_{0}$ は制御に関係しない受動素子を表すインピーダンス， $Z_{i n}$ は電流計測のためのインピーダンス，光し て $Z_{v i r}$ が電圧源により仮想的に実現しようとするインピーダンスを表す．(c) は (b) の $Z_{v i r}$ の部分を制御電圧源 $v_{v i r}$ に置き換えたものであり，制御電圧源はあたかも光こに $Z_{v i r}$ なるインピーダンスが存在するように電圧を出力す るものとする .

$$
\tilde{v}_{v i r}(s)=Z_{v i r}(s) \tilde{i}_{s}(s)
$$

また $Z_{i n}$ の両端の電位差 $v_{i n}$ が計測できるものとすると,$i_{s}$ は $v_{i n}$ を用いて次のように表すことができる.

$$
\tilde{v}_{i n}(s)=Z_{\text {in }}(s) \tilde{i}_{s}(s)
$$

また，仮想インピーダンス $Z_{v i r}(s)$ によってシャント回路全体のインピーダンスが $Z_{s}(s)$ となるためには次式が成立 する必要がある．

$$
Z_{0}(s)+Z_{i n}(s)+Z_{v i r}(s)=Z_{s}(s)
$$

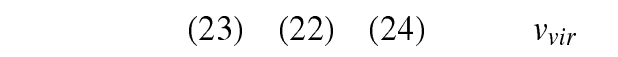

$$
\tilde{v}_{\text {vir }}(s)=\frac{Z_{s}(s)-\left(Z_{0}(s)+Z_{\text {in }}(s)\right)}{Z_{\text {in }}(s)} \tilde{v}_{\text {in }}(s)
$$

と表すことができ，計測できる電圧 $v_{i n}$ と既知のインピーダンス $Z_{0}, Z_{i n}$ ならびに目標インピーダンス $Z_{s}$ を用いて 決定できる . 具体的には, まず $v_{i n}$ を計装アンプなどで計測し, 計測された信号をアナログ電子回路やディジタル 計算機を用いて信号処理を行い, 式 (25)の伝達関数を実現する.光して, 電子回路や計算機のDA コンバータか ら出力される信号では電磁アクチュエータを直接駆動できないため, 電力を増幅するために電圧アンプを用いて $v_{v i r}$ として出力する . 図 7 の (d) は仮想インピーダンス回路の概要であり, 図中 $v_{y}$ は $K_{i n}$ 倍の増幅率をもつ計装ア ンプから出力されコントローラに入力される電圧,$v_{u}$ はコントローラから出力され $K_{\text {out }}$ 倍の増幅率をもつ電圧ア ンプに入カされる電圧を表す．

$$
\left\{\begin{array}{l}
v_{y}=K_{\text {in }} v_{\text {in }} \\
\tilde{v}_{u}=K(s) \tilde{v}_{y} \\
v_{v i r}=K_{\text {out }} v_{u}
\end{array}\right.
$$

式 (25)，(26)より，計算機で実現すべき伝達関数 $K(s)$ は

$$
K(s)=\frac{Z_{S}(s)-\left(Z_{0}(s)+Z_{\text {in }}(s)\right)}{K_{\text {out }} K_{\text {in }} Z_{\text {in }}(s)}
$$

と表すことができる．

本論文では，インピーダンス $Z_{0}$ は使用しないものとし，また電流計測用のインピーダンス $Z_{\text {in }}$ は実抵抗とした 回路を使用する.

$$
\left\{\begin{array}{l}
Z_{0}(s)=0 \\
Z_{\text {in }}(s)=R_{\text {in }}
\end{array}\right.
$$

式 (27) と式 (10)，(16)，(28)より， $K(s)$ は R シャントの場合と RC シャントの場合でとれ光れ以下のように設計 される .

$$
\begin{aligned}
& K^{(\mathrm{Rshunt})}(s)=\frac{1}{K_{\text {out }} K_{\text {in }} R_{\text {in }}}\left(R_{s}^{\mathrm{opt}(\mathrm{Rshunt})}-R_{\text {in }}\right) \\
& K^{(\mathrm{RCshunt})}(s)=\frac{1}{K_{\text {out }} K_{\text {in }} R_{\text {in }}}\left(\frac{1}{C_{s}^{\mathrm{opt}(\mathrm{RCshunt})} s}+R_{s}^{\mathrm{opt}(\mathrm{RCshunt})}-R_{\text {in }}\right)
\end{aligned}
$$




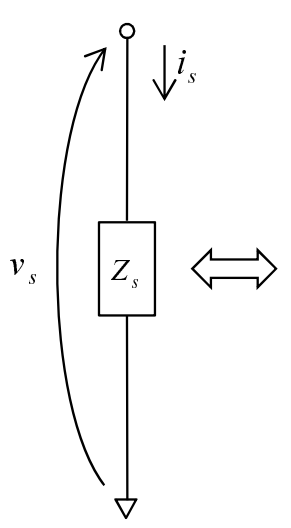

(a)

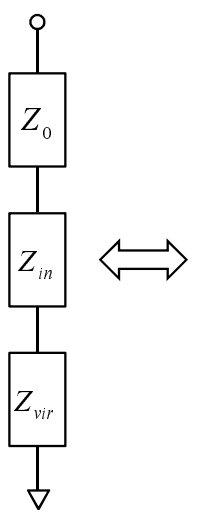

(b)

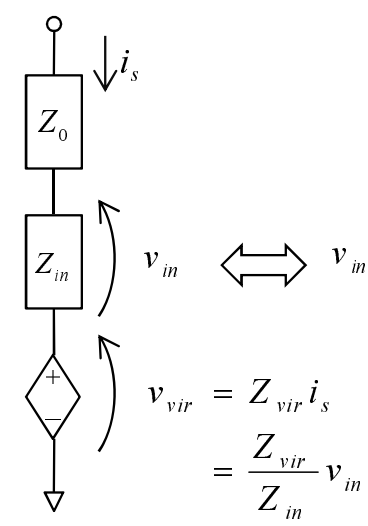

(c)

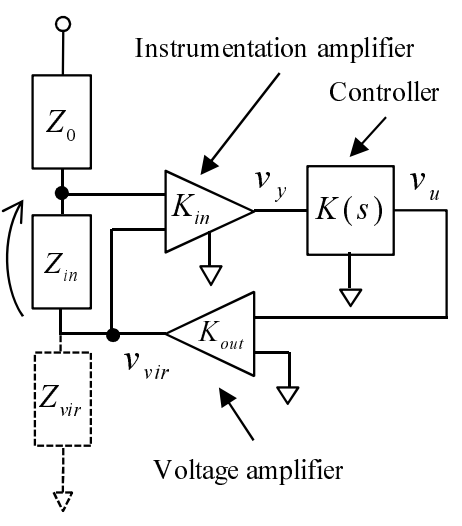

(d)

(a) Original (desired) impedance,(b) Partitioned impedance with three elements,

(c) Voltage source representation, (d) Rea lized virtual impedance circuit

Fig. 7 Concept of the virtual impedance

なお，コントローラの構造について考察を加えると， R シャントでは比例 $(\mathrm{P})$ フィードバック $\mathrm{RC}$ シャントでは 比例積分 (PI) フィードバックになっていることがわかる．一般的な機械構造物の振動制御において，多くの場合 観測する物理量は位置や速度であり，制御入力の物理量は力である .一方，仮想インピーダンス回路を用いたセ ンサレス振動制御系では，観測量と制御入力は光れ光れ電流と電圧であり，電磁アクチュエータのアドミタンスを 介してはじめて機械系と連成している．弚のため，振動制御でよく用いられる速度フィードバック則などは光の ままでは適用できない．またコントローラのパラメータの值によっては制振性能が大きく異なる場合や不安定に なる場合もあるため, 単純なコントローラであっても設計には注意が必要である .

\section{$3 \cdot 2$ 開ループ伝達関数の特性}

物理的な抵抗やキャパシタなどの受動素子を用いた従来の電磁シャント制振では安定性が保証されるため，ディ ジタル仮想インピーダンスで受動素子を模擬した場合にも安定であることが期待される．しかしながら，所望の インピーダンスに非常に近い特性をもつ仮想インピーダンスであっても系が不安定になる可能性がある.例えば， 圧電シャント制振に仮想インピーダンスを適用した場合，圧電素子のアドミタンスの微分特性により高周波にお ける安定余裕がきわめて小さく不安定となるため, 安定化補償が必要となることを著者らは報告している ${ }^{(10)}$. 光 のため電磁シャント制振においても系をコントローラと制御対象に分け, 開ループ特性と安定余裕を調べる必要 がある。

图 8 は仮想インピーダンス回路を接続した場合の等価回路を示す.仮想インピーダンス回路を用いた場合， $Z_{s}(s)$ は受動素子と制御電圧源に置き換えられる．弚こで，式(4)は次のように置き換えられる．

$$
\tilde{v}_{s}(s)=R_{i n} \tilde{i}_{s}(s)+\tilde{v}_{v i r}(s)
$$

図 8 と, 式(3)，(31)から次式が成り立つ.

$$
\left(L s+R_{L}+R_{i n}\right) \tilde{i}_{s}=\tilde{v}_{L}-\tilde{v}_{v i r}
$$

開ループ伝達関数を求めるため, コントローラへの入力端を開放し, 計装アンプからの電圧を $v_{y}$, コントローラ への入力電圧を $v_{y}^{\prime}$ とおく. 開ループにした状態の等価回路を図 9 に示す . $v_{y}^{\prime}$ から $-v_{y}$ までの伝達関数が開ループ 伝達関数になる.式 (1)，(2)，(5)より

$$
\tilde{v}_{L}(s)=-\frac{\phi^{2} s}{m s^{2}+c s+k} \tilde{i}_{s}
$$

となることに注意して, 式 (32)より $\tilde{v}_{L}$ を消去すると, $v_{v i r}$ から $i_{s}$ までの伝達関数 $G_{i_{s} v_{v i r}}(s)$ を求められる.

$$
G_{i_{s} v_{v i r}}(s)=-\frac{m s^{2}+c s+k}{\left(m s^{2}+c s+k\right)\left(L s+R_{L}+R_{i n}\right)+\phi^{2} s}
$$


図 10 に開ループにした場合のブロック線图を示す .一点鎤線で, $G_{i_{s} v_{v i r}}(s)$ を示す. 開ループ妘達関数 $G_{o}(s)=-\tilde{v}_{y} / \tilde{v}_{y}^{\prime}$ は，式 (23)，(26)，(34)から，次のように求まる .

$$
G_{o}(s)=-K_{\text {in }} R_{\text {in }} G_{i_{s} v_{\text {vir }}}(s) K_{\text {out }} K(s)
$$

式 (29) あるいは式 (30) に示した $K(s)$ を式 (35) に代入すると ,

$$
\begin{aligned}
G_{o}^{(\mathrm{Rshunt})}(s) & =-\left(R_{s}^{\mathrm{opt}(\mathrm{Rshunt})}-R_{\text {in }}\right) G_{i_{s} v_{\text {vir }}}(s) \\
G_{o}^{(\mathrm{RCshunt})}(s) & =-\left(\frac{1}{C_{s}^{\mathrm{opt}(\mathrm{RCshunt})} s}+R_{s}^{\mathrm{opt}(\mathrm{RCshunt})}-R_{\text {in }}\right) G_{i_{s} v_{v i r}}(s)
\end{aligned}
$$

となる ．

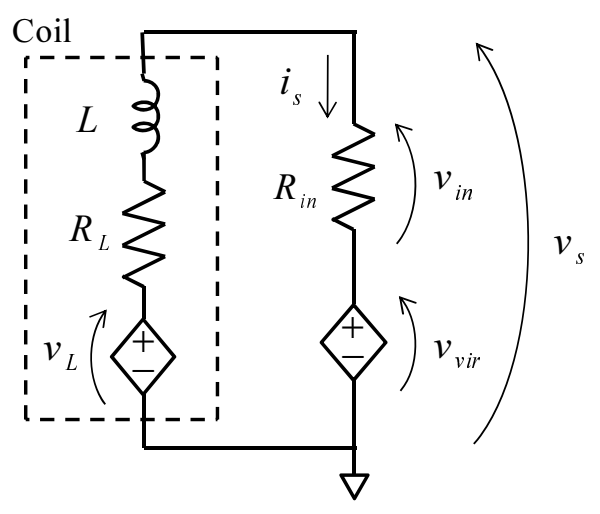

Fig. 8 Equivalent circuit of the virtual impedance

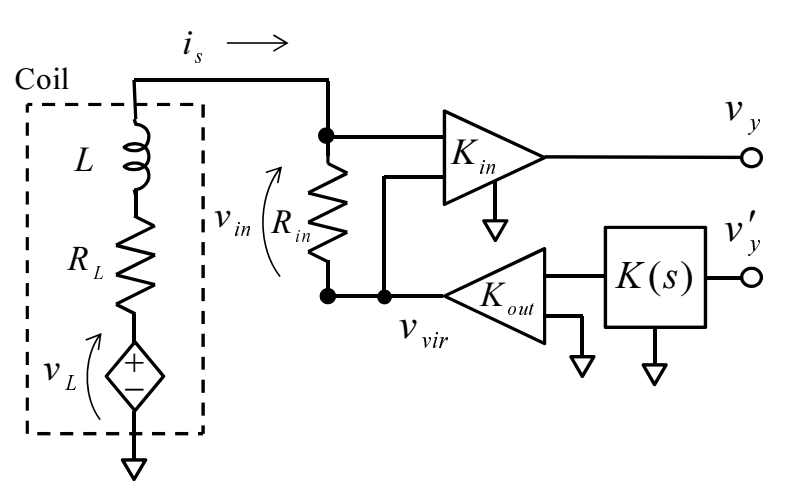

Fig. 9 Open-loop circuit of the virtual impedance

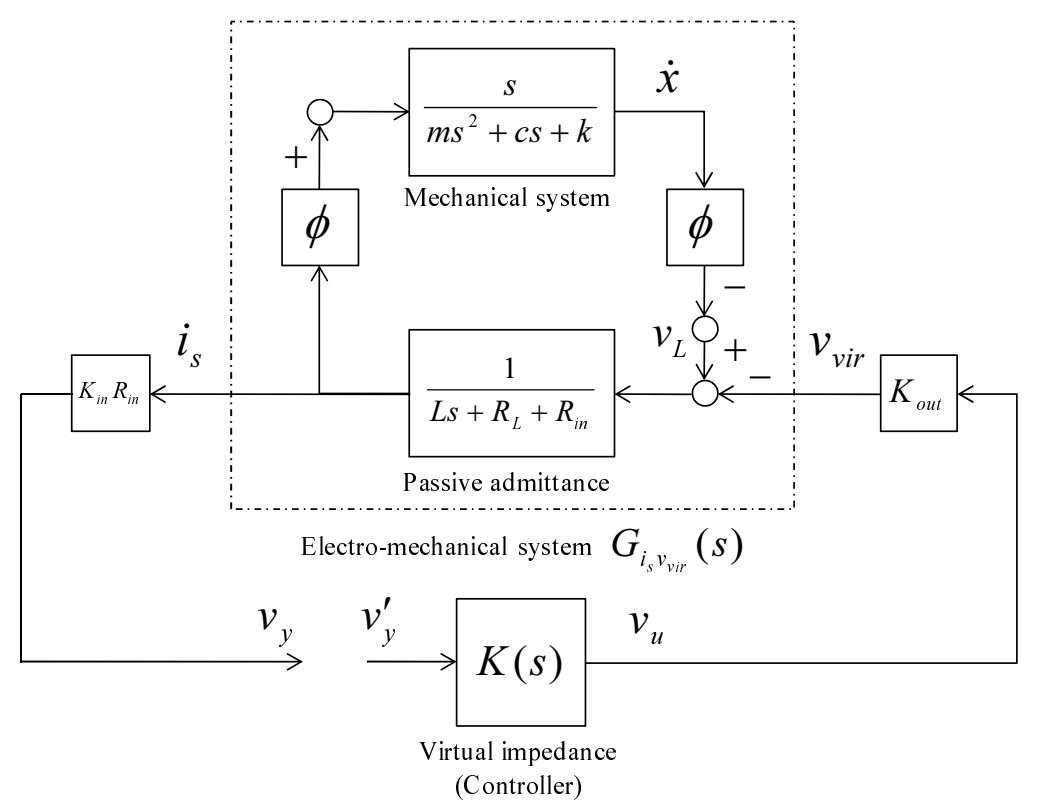

Fig. 10 Block diagram of the open-loop system

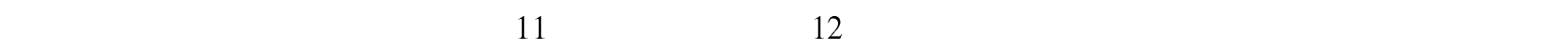
左が $\mathrm{R}$ シャントの場合，右が RC シャントの場合であり，実線は $R_{s}$ として式(15) と (21) の值を用いた場合，一 点鎖線は $R_{S}=0$ とした場合である . なお，図 11 のボード線図において $50[\mathrm{rad} / \mathrm{s}]$ 付近にノッチ状のゲイン低下が みられる.また，図 12 のナイキスト線図においても原点と $-1+0 \mathrm{j}$ の間に小円がみられる .これは, 機械系の共 振周波数が $50[\mathrm{rad} / \mathrm{s}]$ 付近にあり，電気機械結合によって電気系と機械系とが相互作用しているためである．この 
数值例において電気系側 (すなわちコントローラ側) からみた機械系の影響は共振周波数付近で特に顕著にみえる が, 弚れ以外の周波数帯域ではほとんど無視できるようにみえる.

図 $11 ， 12$ から， R シャントと RC シャントともに位相余裕とゲイン余裕か確保され，安定であることがわかる . 产のため, 電磁シャント制振は圧電シャント制振と比較して, ディジタル仮想インピーダンスを適用した場合でも 安定化補償 ${ }^{(10)}$ は不要であるという大きな特長がある. 制御工学の観点からみると，これは信号 $v_{y}$ のところでルー プを切断した開ループ伝達関数 $G_{o}(s)$ が微分特性ではなく積分特性を持つことに起因し, 高周波では十分にゲイン が小さなるためである . 高周波で十分にゲインが小さければ , フィルタの遅れやディジタル制御のむだ時間 , 高 周波でのモデルの不確かさなどに対してロバストである . また , DA 出力は階段状の信号であるが，圧電シャント 制振のようなスパイク電流の問題が生じないため，平滑化フィルタは必要ない．物理的な観点からみると，これ は圧電素子のインピーダンスは容量性であるのに対して電磁アクチュエータは誘導性であり，電流は電圧の積分 に比例しており平滑化されるためである .さらに, 高周波において十分に開ループゲインが小さくなるため，ア ンチエイリアシングフィルタを用いなくとも後述の実験では問題は生じなかった . 兴のため , 仮想インピーダン ス回路による方法は，電磁シャント制振をディジタル化するのに適した回路構成であるといえる .

なお，図 11，12 から，系の安定余裕について以下のことがわかる.実線の理想的な場合では， $\mathrm{R}$ シャントでは ゲイン余裕約 $1[\mathrm{~dB}]$ ，位相余裕無限大， RC シャントではゲイン余裕約 $0.47[\mathrm{~dB}]$ ，位相余裕約 $16.2[\mathrm{deg}]$ である .こ のように安定余裕が小さいのは $R_{S}^{\mathrm{opt}}<0$ として負の抵抗值を実現したためと考えられる. 一点鎖線に示す $R_{s}=0$ とおいた場合はシャント回路を短絡したことに相当し, 開ループゲインが非常に小さくなることから大きな安定 余裕を持つことがわかる．しかしながら，光の場合には図 6 にも示したように制振効果はほとんど無い .
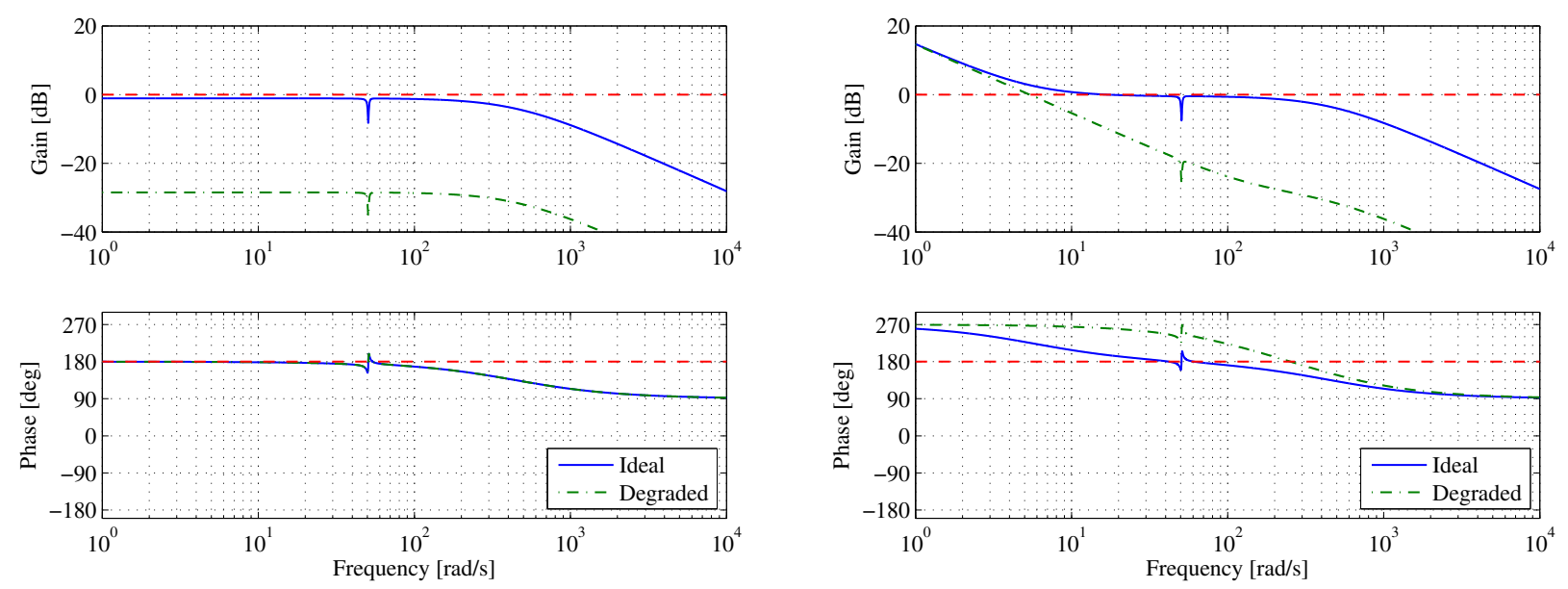

Fig. 11 Bode diagram of the open-loop transfer function $G_{o}$ (left: R shunt, right: RC shunt)
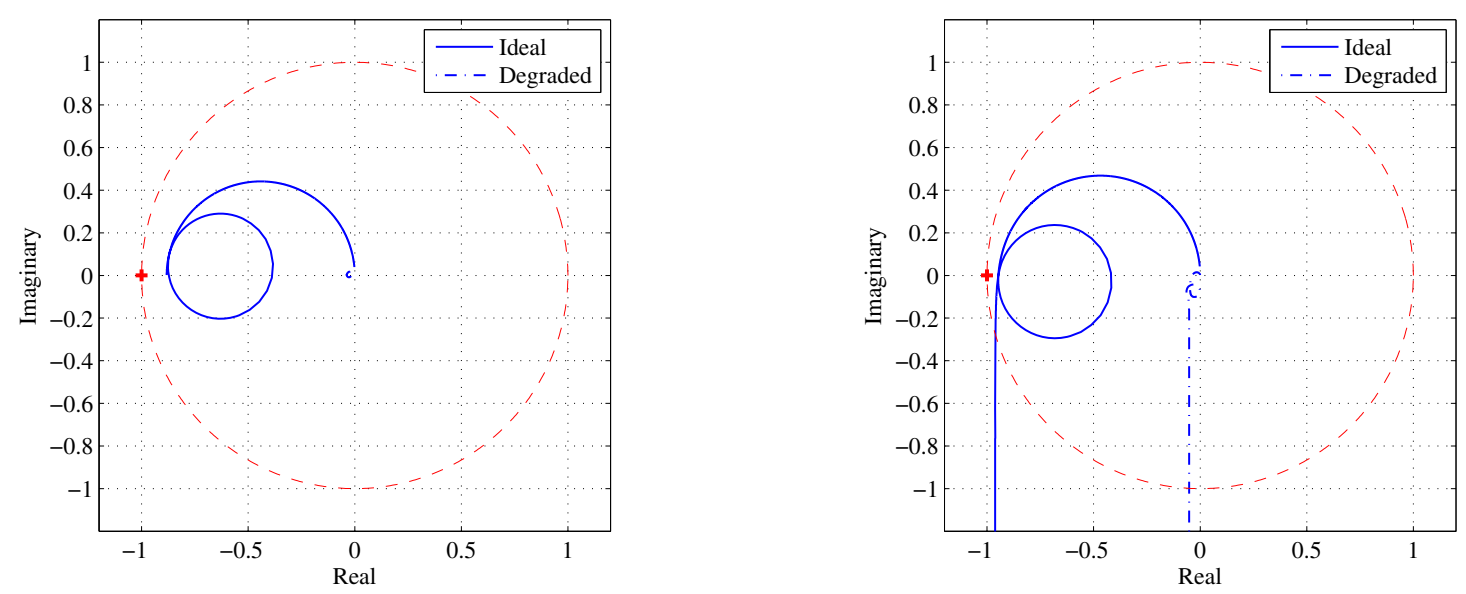

Fig. 12 Nyquist diagram of the open-loop transfer function $G_{o}$ (left: R shunt, right: RC shunt) 


\section{4. 実 験}

\section{1 方法}

実験装置の概略を図 13 に示す.直動ベアリングにより水平 1 自由度の運動に制限された台車に，制振用の電磁 アクチュエータと外乱用の電磁アクチュエータが取り付けられている．制振用の電磁アクチュエータは, 240 巻の コイルと，公称残留磁束密度 $1.34[\mathrm{~T}]$ の永久磁石ならびに磁気回路からなる (図 1 右). 磁力線が横切る位置を考慮

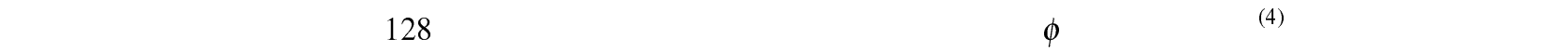
密度は約 0.334 [T] である. 制振用の電磁アクチュエータには, 電流計測用の抵抗 $R_{\text {in }}$ と計装アンプ (INA128, Texas Instruments) , パワーOP アンプ(LM675, National Semiconductor)からなる仮想インピーダンス回路と DSP(s-BOX, $\mathrm{mtt})$ が接続されている . IC により実装した仮想インピーダンス回路の回路図を図 14 に示す . $v_{u}$ は DSP の DAボー ドからの信号， $v_{y}$ は DSP の $\mathrm{AD}$ ボードへの信号を表す.計装アンプが接続されている電流計測用の抵抗 $R_{i n}$ は $\mathrm{S} / \mathrm{N}$ 比の向上のためできるだけ大きな值が望ましいが, $R_{s}^{\mathrm{opt}}$ よりは小さな值が望ましいため公称值 $0.1[\Omega], 2[\mathrm{~W}]$ の抵抗を用いた . 電流計測用の計装アンプの倍率 $K_{\text {in }}$ は約 100 倍とした.$R_{\text {in }}$ と $K_{\text {in }}$ の值は表 3 に示す. 計測さ れた電流は DSP の AD コンバータによって 5000[Hz] でサンプリングされ, MATLAB(MathWorks) の Simulink と RealTimeWorkshop によってプログラムされたコントローラに入力される . なお , サンプリング周波数は固有振動 数に比べて十分に高く，離散化に伴う誤差は無視できるものとする . DSP の出力のDA コンバータにはパワーOP アンプを用いた非反転増幅器が接続され，指令值に応じた電圧を制振用電磁アクチュエータに加えられるように なっている.なお , パワーOP アンプの発振を防ぐため, 非反転増幅器への入力電圧を $1 / 21$ に分圧したうえで OP アンプの増幅率を 21 倍とし , また出力側に $1[\Omega]$ の抵抗と $0.22[\mu \mathrm{F}]$ のキャパシタが直列接続されている(12).

また，外乱用電磁アクチュエータは電流アンプとファンクションジェネレータが接続されており, 加振を行う ことができる．振動によって生じる台車の変位はレーザ変位計によって計測する．制振対象とする台車に関する 機械的パラメータ $m, c, k$ を求めるため, 台車を自由振動させて享の周期から減衰固有角振動数と減衰比を求めた . さらに $0.645[\mathrm{~kg}]$ の付加質量を台車に乗せた場合の減衰固有角振動数との比較から，質量とばね係数を求めた . 得 られた機械系パラメータ $m, c, k$ を表 4 に示す. 電気機械結合係数は速度と誘導起電力の比から求める. 台車を正 弦波加振し，光のときの変位とコイル端子間開放電圧とを測定する．電圧の振幅を変位の振幅で除し加振角振動 数を乗ずることにより，電気機械結合係数 $\phi[\mathrm{Vs} / \mathrm{m}]$ を求める . 共振周波数である 8.1[Hz] 付近の 7.8[Hz] 8.4[Hz] で正弦波加振し, 起電力と速度の振幅比の平均をとって $\phi$ を $1.88[\mathrm{Vs} / \mathrm{m}]$ と推定した．電気的特性の計測は, 台車 が動かないように固定し，インピーダンスアナライザを用いてインダクタンス $L$ と等価直列抵抗 $R_{L}$ を求めた . 表 4 に值を示す. また表 5 は, 得られた物理パラメータをもとに式 $(15),(21)$ から計算された最適な素子值である .

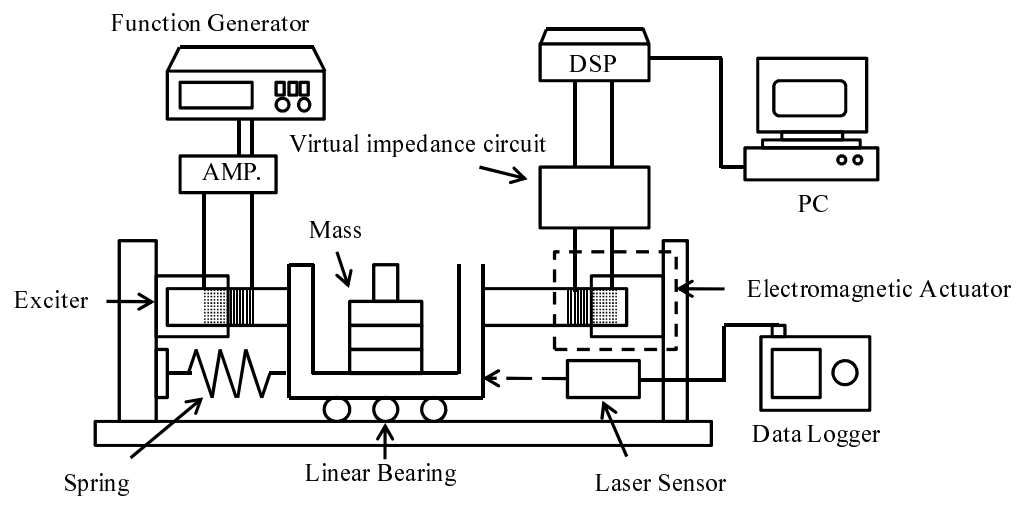

Fig. 13 Schematic of the experimental setup

\section{2 結果}

電磁シャントダンパの制振効果を確認するため, 仮想インピーダンス回路をコイルの両端に接続した状態で , 外 乱用のアクチュエータを用いて 4[Hz]〜12[Hz] まで約 165 秒間かけスイープ加振した . 外乱用アクチュエータへ の加振信号とレーザセンサの信号とをデータロガーに取り込んだ . 図 15 は , 台車の変位を示したものである .上 から，端子間開放の場合， $\mathrm{R}$ シャントの場合， $\mathrm{RC}$ シャントの場合であり，最大の振幅は炎れ攵れ約 $5.2[\mathrm{~mm}]$, 約 


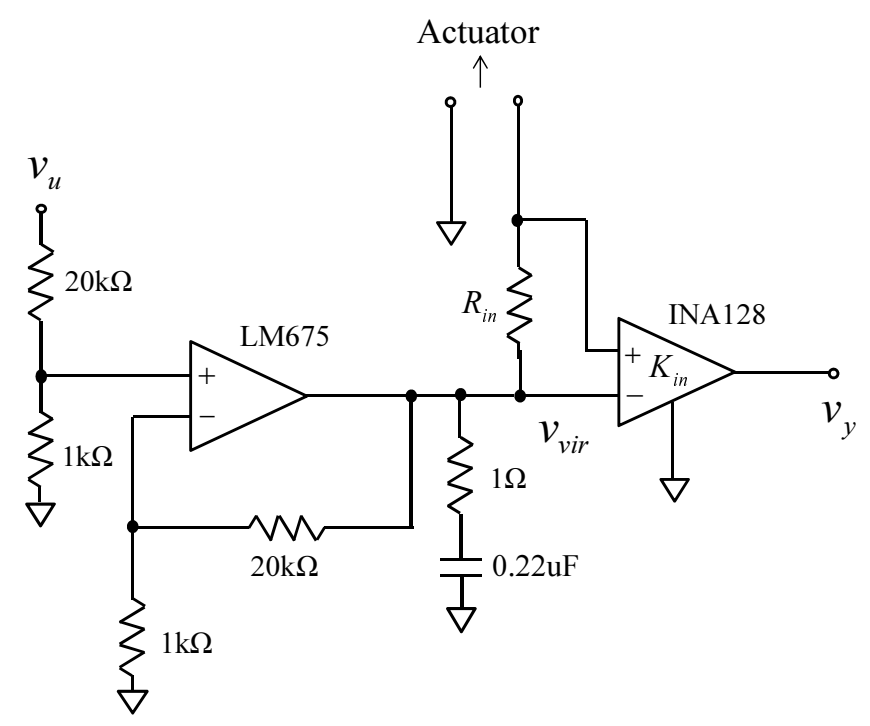

Fig. 14 Implemented virtual impedance circuit

Table 4 Parameters of the mechanical system with a shunted electromagnetic actuator

Table 3 Parameters of the virtual impedance circuit

\begin{tabular}{llr}
\hline \hline$R_{\text {in }}$ & {$[\Omega]$} & 0.098 \\
$K_{\text {in }}$ & {$[\mathrm{V} / \mathrm{V}]$} & 99.2 \\
$K_{\text {out }}$ & {$[\mathrm{V} / \mathrm{V}]$} & 1.00 \\
\hline \hline
\end{tabular}

\begin{tabular}{|c|c|}
\hline$m[\mathrm{~kg}]$ & 1.71 \\
\hline$c \quad[\mathrm{Ns} / \mathrm{m}]$ & 1.05 \\
\hline$k \quad[\mathrm{~N} / \mathrm{m}]$ & $4.38 \times 10^{3}$ \\
\hline$\phi \quad[\mathrm{Vs} / \mathrm{m}],[\mathrm{N} / \mathrm{A}]$ & 1.88 \\
\hline$L \quad[\mathrm{H}]$ & $5.83 \times 10^{-3}$ \\
\hline$R_{L}[\Omega]$ & 2.5 \\
\hline
\end{tabular}

Table 5 Designed parameters of the virtual impedance

\begin{tabular}{ll}
\hline$R_{S}^{\text {opt(Rshunt) }}[\Omega]$ & -2.19 \\
$R_{S}^{\text {opt(RCshunt) }}[\Omega]$ & -2.37 \\
$C_{S}^{\text {opt(RCshunt) }}[\mathrm{F}]$ & 0.0718 \\
\hline \hline
\end{tabular}

$0.8[\mathrm{~mm}]$, 約 $0.4[\mathrm{~mm}]$ である .また実験は光れ吕 3 回繰り返して行い , パワースペクトルとクロススペクトルの 平均値をもとに周波数応答関数を求めた.

開放した場合と仮想 R シャント回路を用いた場合の比較を図 16 左に示す . 図は上からコヒーレンス，ゲイン， そして位相を表す . 開放した場合に比べ $\mathrm{R}$ シャント制振はゲインがー $18.8[\mathrm{~dB}]$ 低減できており，図からもピークゲ インが大きく低減できていることがわかる．なお数值例で求めた場合の $-17[\mathrm{~dB}]$ と比べ多少の誤差はあるが，十 分に近い值である. なお誤差の原因としては，あらかじめ推定した物理パラメータの誤差により調整された值が 最適値からずれている可能性や，推定した減衰係数が大きく見積もられている可能性などが考えられる．

$\mathrm{R}$ シャントの場合と同樣に，RC シャントの場合の測定を行った . 回路を開放した場合との比較を図 16 右に示 す . RC シャントにより, 開放した場合に比ベピークゲインがー25.4[dB] 低減されており, Rシャントよりもさら に良好な制振効果か確認できた .これは数値例で求めた理論值 $-26.5[\mathrm{~dB}]$ と比べ多少ゲインが異なっているが ,十 分近い值であると言える．

\section{5. おり り に}

本研究では, ディジタル制御された仮想インピーダンス回路を電磁アクチュエータを用いたダンパに適用してセ ンサレス制振を行う方法と，乥の簡易な設計法を提案した . 系の支配方程式を導き， Rシャント，RCシャントを 設計する際の安定性の条件と定点理論を用いた設計式を示した . 光して, 仮想インピーダンス回路の実装方法に ついて述べた . 仮想インピーダンス回路を用いることで, 従来の受動 RC 回路では不可能な負性抵抗を容易に実現 でき, 定点理論の意味で最適な抵抗値をもつ回路の実現が可能である．また，仮想インピーダンス回路を用いる 


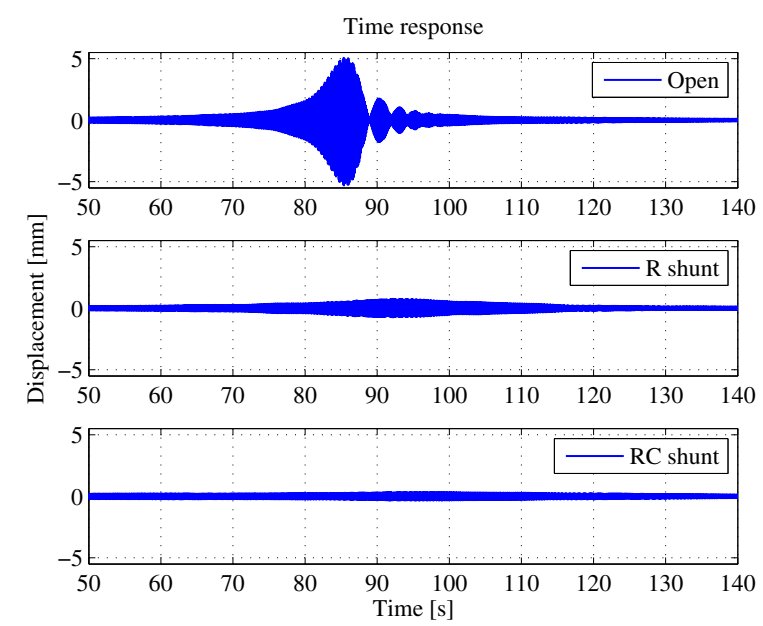

Fig. 15 Experimental time response
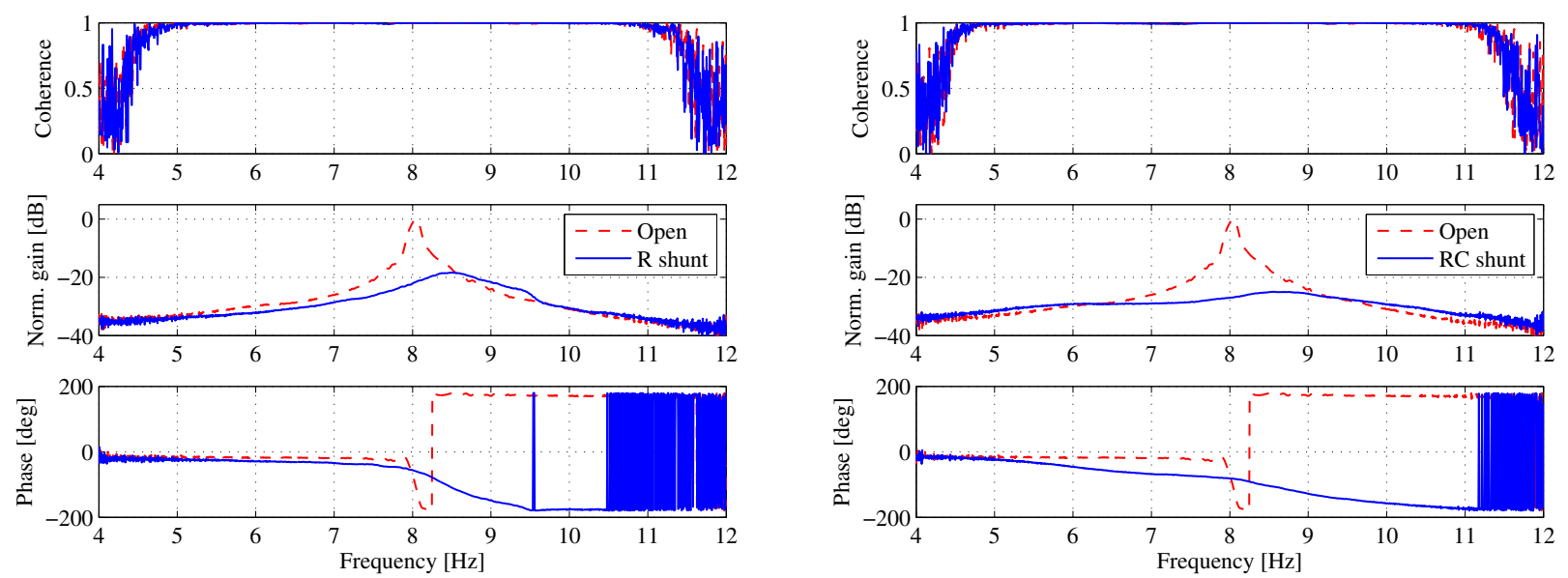

Fig. 16 Experimental frequency response (left: $\mathrm{R}$ shunt, right: $\mathrm{RC}$ shunt)

と電磁アクチュエータのインピーダンス特性によって開ループ伝達関数が好ましい特性をもつため, 圧電シャン 卜制振では必要であった安定化補償や平滑化フィルタなどが不要になることを指摘した．最後に実験により，ディ ジタル仮想インピーダンスを用いた R シャント， RC シャントによって良好な制振ができることを示した．今後， ディジタル制御による設計の自由度を活用しセンサレス電磁制振のさらなる高度化が期待される。

$$
\text { 文献 }
$$

（1）永井文秀，原田秀行，米村淳一，岡田養二, “エネルギー回生ダンパの研究”, 日本機械学会論文集 C 編, Vol.63, No.611, (1997), pp2237-2242 .

（2）須田義大，中代重幸，中野公彦，“回生された振動エネルギーを利用するアクティブ制御に関する研究”, 日本機械学会論 文集 C 編，Vol.63，No.613，(1997),pp.3038-3044 .

(3) 金尚洙, 米村淳一, 岡田 養二, 柴田 昌明, “共振回路を用いたエネルギー回生ダンパとサスペンションの研究”, 日本 AEM 学会誌, Vol.7, No.2, (1999), pp171-178.

（4）井上剛志，石田幸男，角正貴，“電磁共振ダンパによる振動制御”, 日本機械学会論文集 C 編，Vol.70，No.697，(2003), pp.2565-2572.

(5) Behrens, S., Fleming, A.J., and Moheimani, S.O.R., "Passive Vibration Control via Electromagnetic Shunt Damping", IEEE/ASME Transactions on Mechatronics, Vol.10, No.1, (2005), pp.118-122.

（6）安達和彦, “圧電ダンパを用いた構造物の制振”, 計測と制御, Vol. 42, No. 9 , (2003), pp.763-769. 
(7) 瀧上唯夫, 富岡隆弘, “ピエゾ素子を用いた鉄道車両の弾性振動低減: 特性変化による性能劣化防止に関する検討”,Dynamics and Design Conference 2004 講演論文集, (2004), 543.

(8) 瀧上唯夫, 富岡隆弘, Joel, H., “ピエゾ素子を用いた鉄道車両の弾性振動低減 : 新幹線車体 $1 / 5$ 模型による検討”, 日本機械学 会論文集 C 編, Vol. 71, No. 704, (2005), pp.1254-1262.

(9) Takigami, T., Tomioka, T., "Bending Vibration Suppression of Railway Vehicle Carbody with Piezoelectric Elements : Experimental Results of Excitation Tests with a Commuter Car", Journal of Mechanical Systems for Transportation and Logistics, Vol. 1, No. 1, (2008), pp.111-121.

(10) 松井 德志, 高木 賢太郎, 井上 岡志, 瀧上唯夫 , “ディジタル仮想インピーダンスによるLR 回路を用いた圧電シャント制振 のための安定化補償”, 日本機械学会論文集 C 編, Vol. 77, No. 777, (2011), pp.1781-1792.

（11）伊藤正美, 自動制御概論 (上)，昭晃堂，(1996)

(12) National Semiconductor, "LM675 Power Operational Amplifier General Description”, National Semiconductor Data Sheet, DS006739, (2004), retrieved June 262009. 